\title{
EVALUATION OF SELF-INCOMPATIBILITY LOCUS DIVERSITY OF DOMESTIC PLUM (Prunus domestica L.) USING DNA-BASED $S$-GENOTYPING
}

\author{
Irita Kota-Dombrovska and Gunārs Lācis \\ Latvia State Institute of Fruit-Growing, Graudu iela 1, Dobele, LV-3701, LATVIA \\ irita.kota@Ivai.Iv
}

Communicated by Isaak Rashal

\begin{abstract}
There is limited information on genetics of self-incompatibility in domestic plum (P. domestica L.). In comparison with other Prunus species, there are no S-allele specific markers for the identification of compatibility groups, and thus, genetic diversity of self-compatibility genes is not clear. Six S-locus-specific markers previously used for other Prunus species were used to study genetics of self-compatibility of plums, and 33 domestic plum cultivars were genotyped. The applied primer pairs showed good transferability among Prunus species and showed high diversity in the tested plant material (14-37 alleles per marker, average observed heterozygocity - 0.953). Applification of the tested primer pairs allowed discrimination of all plum cultivars by unique S-genotypes. Based on the obtained results, primer pairs EM-PC2consFD/ EM-PC3cons RD, PasPcons-F1/ PaC1cons-R1 and F-Box50A/ F-Box intronR are suggested as supplementary markers for characterisation and identification of plum germplasm with potential functional relevance. Although the markers used did not strictly distinguish plum cultivars according to compatibility groups (selfcompatible, partly self-compatible and self-incompatible), group-unique amplification fragments were identified, which can serve as a baseline in further development of specific markers.
\end{abstract}

Key words: Prunus, plums, self-incompatibility, genetics, molecular markers.

\section{INTRODUCTION}

Domestic plum (Prunus domestica L.) is hexaploid $(2 \mathrm{n}=$ $6 \mathrm{x}=48$ ) allopolyploid species of the Rosaceae family (Botu et al., 2002). It is assumed that domestic plum is a naturally formed hybrid that originated about 2000 years ago from diploid $(2 \mathrm{n}=16)$ myrobalan $(P$. cerasifera $)$ and tetraploid $(2 \mathrm{n}=32)$ P. spinosa L. plums (Zohary and Hopf, 2000). Thus, domestic plum has a three-component genome (D1D2C), with genetic formula D1D1D2D2CC, where part $\mathrm{C}$ represents the genome of diploid myrobalan plum inherited into domestic plum (Botu et al., 2002; Decroocq et al., 2004). Plants of the Prunus genus have a gametophytic self-incompatibility system. However, unlike other Prunus species, domestic plum has both sporophytic and gametophytic incompatibility systems (Botu et al., 2002). Sporophytic incompatibility is determined by a mutation in the locus responsible for pollen formation and cytoplasmatic sterility. The gametophytic incompatibility system is based on allele polymorphism in the $S$-RNase coding gene $(S$-gene) and determines three types of pollination: complete compatibility, partial compatibility and complete incompatibility (Botu et al., 2002). Due to the three component genome it is difficult to find the same allelic formula or structure for two domestic plum cultivars, since each genome has its own $S$-gene with multiple alleles. For this reason, any plum cultivar having fertile pollen can pollinate any other cultivar, but in different degrees (Selesses and Bonnet, 1994). Extensive studies on self-compatibility have been conducted on other Prunus species: sweet cherries ( $P$. avium L.) (e.g. Lacis et al., 2008; Ipek et al., 2011), sour cherries (P. cerasus L.) (e.g. Tsukamoto et al., 2008), apricots (P. armeniaca L.) (e.g. Jie et al., 2005; Donoso et al., 2009) and on some diploid plum species, such as Japanese plum (P. salicina Lindl.) (e.g. Hegedüs and Halisz, 2007; Guerra et al., 2009) and myrobalan plum (P. cerasifera Ehrh.) (Sutherland et al., 2009). Domestic plum is the least-investigated species in the Prunoideae subfamily, which is partly due to its polyploidy and complex structure of genome (Selesses and Bonnet, 1994; Botu et al., 2002; Decroocq et al., 2004; Hegedüs and Halász, 2007; Sutherland et al., 2007; Tao and Iezzoni, 2010). The compatibility groups of domestic plum cultivars are not defined and there is no clear information about genetic diversity of self-incompatibility alleles.

The plum germplasm collection at the Latvia State Institute of Fruit-Growing (LSIFG) contains a wide diversity of domestic plum cultivars (Kaufmane et al., 2006; Kārkliņš et al., 2007) representing diverse geographic origin (Belarus, 
Canada, Estonia, France, Germany, Italy, Latvia, Lithuania, Norway, Russia, Sweden, Ukraine, USA, etc.). Since the incompatibility problem has always been stressed by fruit growers, cytoembryological investigations on plums grown in Latvia have been performed (Kaufmane, 1991). The DNA-based research is in the first steps of implementation (Kota and Lācis, 2013) and S-alleles, which determine pollination compatibility, have not yet been studied in plum cultivars and their genetic diversity has not been evaluated. Lack of this information limits detailed characterisation of germplasm, breeding efforts and appropriate orchard design. The aim of the study was to perform DNA-based $S$-genotyping to evaluate genetic diversity of the $S$-locus in plum germplasm and to characterise possible $S$-allele composition and occurrence.

\section{MATERIAL AND METHODS}

Plant material. The study was performed at LSIFG on 33 domestic plum (Prunus domestica L.) cultivars. Eleven self-compatible, six partly self-compatible and sixteen selfincompatible cultivars were included in the study. Allocation of cultivars to a particular group of self-incompatibility was based on published cultivar descriptions (Kaufmane, 1991; Kārklinšs et al., 2007), fertilisation field evaluation and cytoembryology research (Kaufmane, 1991).

Isolation of genomic DNA. Total DNA was isolated from young leaves using a Genomic DNA Purification Kit (Fermentas, Lithuania). The quantification and quality evaluation of DNA was performed by a spectrophotometer NanoDrop 1000 (NanoDrop products, USA).

PCR and fragment analysis. S-genotyping of domestic plum cultivars was performed using five pairs of consensus primers spanning the first and second introns of S-RNase gene (Fig. 1). One primer pair was used to amplify the intron of the SFB gene responsible for pollen-associated selfincompatibility.
Fluorescently labelled primers PaSPons-F1 (Vaughan et al., 2006) and PaC1cons-R1 (Sonneveld et al., 2006) were used in PCR to amplify the $S$-RNase first intron and F-BOX50A and F-BOXintronR (Vaughan et al., 2006) to amplify the SFB intron. Touch-down PCR was employed with cycling of $95{ }^{\circ} \mathrm{C}$ for $15 \mathrm{~min}$ followed by 10 cycles of $94{ }^{\circ} \mathrm{C}$ for $30 \mathrm{~s}$, $55{ }^{\circ} \mathrm{C}$ for $90 \mathrm{~s}$ with a reduction of annealing temperature by $0.5{ }^{\circ} \mathrm{C}$ per cycle, with final elongation $72{ }^{\circ} \mathrm{C}$ for $60 \mathrm{~s}$, then 25 cycles of $94{ }^{\circ} \mathrm{C}$ for $30 \mathrm{~s}, 48{ }^{\circ} \mathrm{C}$ for $90 \mathrm{~s}, 72{ }^{\circ} \mathrm{C}$ for $60 \mathrm{~s}$ and a final elongation of $60{ }^{\circ} \mathrm{C}$ for $30 \mathrm{~min}$ (Vaughan et al., 2006).

PCR amplification products obtained using fluorescently labelled primers were collected and allele sizes determined using a ABI PRISM ® 3100 Genetic Analyzer (Applied Biosystems) and genotyping programme GeneMapper $(\AA$ Software v4.0 (Applied Biosystems).

Six degenerate primers were used for amplification of the $S$-RNase second intron (Fig. 1). Three of them were EM-PC2consFD (C2), EM-PC3consRD (C3) and EM-PC5consRD (C5) (Sutherland et al., 2004). These EM primers were used in combinations $\mathrm{C} 2+\mathrm{C} 3$ and $\mathrm{C} 2+\mathrm{C} 5$. PCR conditions were as follows: initial denaturation at 94 ${ }^{\circ} \mathrm{C}$ for $2 \mathrm{~min}$ and 35 cycles of $94{ }^{\circ} \mathrm{C}$ for $10 \mathrm{~s}, 56{ }^{\circ} \mathrm{C}$ for 2 min and $68{ }^{\circ} \mathrm{C}$ for $2 \mathrm{~min}$, with an increment of $10 \mathrm{~s}$ per cycle on the extension step after the $10^{\text {th }}$ cycle of amplification (Sutherland et al., 2004). Another three applied primers were PruT2, PruC2 (Tao et al., 1999) and PCE-R (Ushijima et al., 1998). The primer pair combinations used for PCR amplification were PruT2 + PCE-R and PruC2 + PCE-R. PCR conditions were: an initial step of $3 \mathrm{~min}$ at $94{ }^{\circ} \mathrm{C}, 35$ cycles of $1 \mathrm{~min}$ at $94{ }^{\circ} \mathrm{C}, 1 \mathrm{~min}$ at $56{ }^{\circ} \mathrm{C}$ and $3 \mathrm{~min}$ at $72{ }^{\circ} \mathrm{C}$, and a final step of $7 \mathrm{~min}$ at $72{ }^{\circ} \mathrm{C}$ (Guerra et al., 2009). Amplification products were separated on $2 \%$ TAE agarose gel in 1X TAE buffer and stained with ethidium bromide. A 100 bp DNA ladder (O'RangeRuler 100 bp DNA Ladder, Fermentas, Lithuania) was used for fragment size determination.

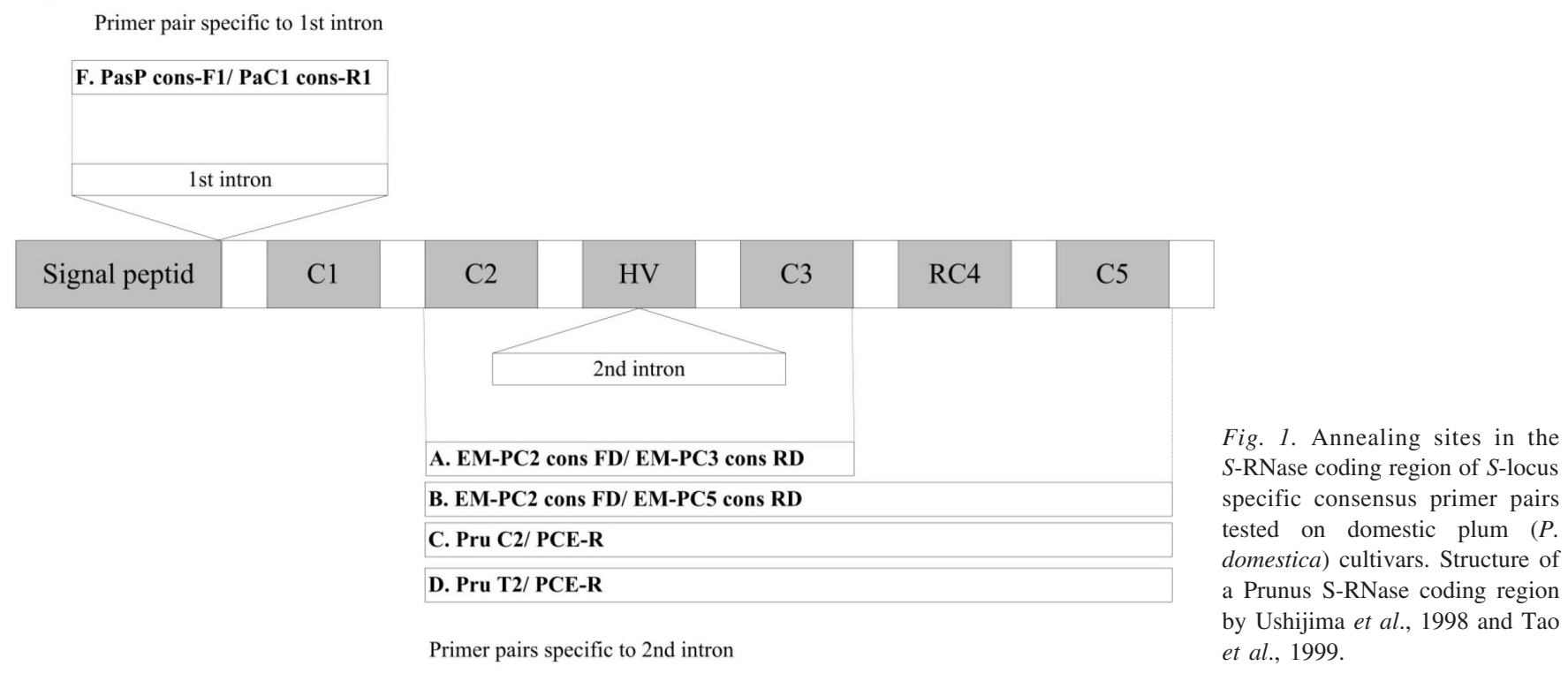


CHARACTERISTICS OF $S$-RNASE AND SFB INTRON FLANKING CONSENSUS PRIMER PAIRS AND THEIR ABILITY TO DISCRIMINATE PLUM CULTIVAR SELF-COMPATIBILITY GROUPS

\begin{tabular}{|c|c|c|c|c|c|c|c|}
\hline \multirow[t]{2}{*}{ Praimer pair } & \multirow{2}{*}{$\begin{array}{c}\text { Number of } \\
\text { amplification } \\
\text { fragments }\end{array}$} & \multirow{2}{*}{$\begin{array}{l}\text { Fragment } \\
\text { length range } \\
\text { (bp) }\end{array}$} & \multirow[t]{2}{*}{$\begin{array}{c}\text { Observed } \\
\text { heterozygocity }\end{array}$} & \multirow[t]{2}{*}{$\begin{array}{l}\text { Gene diversity } \\
\text { [PIC value] }\end{array}$} & \multicolumn{3}{|c|}{$\begin{array}{l}\text { Ability to discriminate plum cultivar } \\
\text { self-compatibility groups according to AMOVA }\end{array}$} \\
\hline & & & & & $\begin{array}{l}\text { Number of } \\
\text { discriminative } \\
\text { amplification } \\
\text { fragments }\end{array}$ & $\begin{array}{c}\text { Range of } \\
\text { variability among } \\
\text { plum cultivar } \\
\text { self-compatibility } \\
\text { groups, \% }\end{array}$ & $\begin{array}{l}\text { Mean variability } \\
\text { among plum } \\
\text { cultivar } \\
\text { self-compatibility } \\
\text { groups, } \%\end{array}$ \\
\hline A. EM-PC2consFD/ EM-PC3consRD & 20 & $270-3000$ & 1.000 & 0.929 & 9 & $1-35$ & 12.9 \\
\hline B. EM-PC2consFD/ EM-PC5consRD & 19 & $490-2500$ & 0.935 & 0.915 & 9 & $1-42$ & 12.4 \\
\hline C. PruC2/ PCE-R & 14 & $300-1970$ & 1.000 & 0.885 & 6 & $7-33$ & 16.8 \\
\hline D. PruT2/ PCE-R & 16 & $700-2600$ & 0.909 & 0.911 & 7 & $2-40$ & 18.1 \\
\hline E. F-Box50A/ F-Box intronR & 19 & $196-235$ & 0.875 & 0.907 & 8 & $1-12$ & 6.1 \\
\hline F. PasPcons-F1/ PaC1cons-R1 & 31 & $236-422$ & 1.000 & 0.942 & 12 & $1-40$ & 12.3 \\
\hline Average: & 19.8 & - & 0.953 & 0.915 & 8.5 & - & 13.1 \\
\hline
\end{tabular}

Data analysis. Detected PCR amplification fragments (bands) were coded as present (1) or absent (0) in a binary matrix for statistical analyses. Genetic parameters of tested primer pairs were calculated, as well as Analysis of Molecular Variance (AMOVA) and Principal Component Analysis (PCA) were performed to estimate genetic diversity using GenAlEx 6.4.1 software (Peakall and Smouse, 2006).

\section{RESULTS}

S-allele genotyping. All six tested primer pairs exhibited successful PCR amplification and generated amplification products for 30 plum cultivars, with 14 to 31 amplification fragments identified per marker (21.2 in average) (Table 1) showing high genetic diversity. The highest number of amplification fragments was determined for primer pair PasPcons-F1/PaC1cons-R1, and in primer pair PruC2/ PCE-R (Table 1). Application of six tested primer pairs allowed discrimination of all plum cultivars by unique $S$-genotype. Amplification was not successful only for cultivars 'Ave' (using primer pair F-Box50A/F-BoxintronR), 'Gult Äggplomon' (using primer pairs EM-PC2consFD/EMPC3consRD and EM-PC2consFD/EM-PC5consRD) and 'Zīlǐšu Sarkanā Olplūme' (primer pair EM-PC2consFD/ EM-PC5consRD). Full $S$-genotypes (six amplification fragments) were obtained for four plum cultivars ('Lāse', 'Lāse clone 1', 'Melnā Renklode' and 'Ullenas Renklode') using primer pair EM-PC2consFD/ EM-PC3consRD. Partial $S$-genotypes (1-5 amplification fragments identified) were obtained for other plum cultivars, since there was no information on particular fragment copy number or genomic organisation. Heterozygosity for primer pairs ranged from 0.875 to 1.000 with an average value of 0.953 (Table 1). Gene diversity values varied from 0.885 to 0.942 , with an average value of 0.915 (Table 1).

Since domestic plum is hexaploid, a maximum of six amplification fragments can be found in one sample. Consensus primer pair PasPcons-F1/ PaC1cons-R1 flanking the first intron of $S$-RNase gene amplified two or five amplification fragments (ranging from 236 to $422 \mathrm{bp}$ ) (Table 1). Primer pairs EM-PC2consFD/ EM-PC3consRD, EM-PC2consFD/ EM-PC5consRD, PruC2/ PCE-R and PruT2/ PCE-R ensured amplification of the second intron of the $S$-RNase gene (Fig. 1). Primer pair EM-PC2consFD/EMPC3consRD amplified two or six putative alleles (ranging from 270 to $3000 \mathrm{bp}$ ), primer pair EM-PC2consFD/ EM-PC5consRD had one to five amplification fragments per domestic plum sample (ranging from 490 to $2500 \mathrm{bp}$ ), whereas primer pair PruC2/ PCE-R amplified two to five amplification fragments (ranging from 300 to $1970 \mathrm{bp}$ ) and primer pair PruT2/ PCE-R had one to six fragments, ranging from 700 to $2600 \mathrm{bp}$ (Table 1). Consensus primer pairs specific for the SFB intron (F-Box50A/ F-Box intronR) amplified one or five amplification fragments (range 196 to 235 bp) (Table 1).

Marker EM-PC2consFD/ EM-PC3consRD had the highest number of amplification fragments per sample (4.0 in average), followed by PasPcons-F1/ PaClcons-R1 (3.9). The smallest number of fragments per sample was for primer pairs PruT2/ PCE-R and F-Box50A/ F-Box intronR (2.9 in average). The most common number of amplification fragments per individual sample was three and four, and the most seldom number was one and six fragments (Fig. 2). This was observed for all studied markers and could be described by a normal distribution (Fig. 2). Primer pair Pru T2/ PCE-R had comparatively high frequency of cases with two amplification fragments per sample, whereas primer pairs EM-PC2consFD/ EM-PC3consRD and PasPcons-F1/ PaClcons-R1 had high frequency of five fragments per sample (Fig. 2).

Plum compatibility groups. Eleven self-compatible, six partly self-compatible and sixteen self-incompatible cultivars were genotyped in the study. Significant differences were found in the total number of fragments between compatibility groups of domestic plums. The highest number of amplification fragments was found in the group of self-incompatible plums (93) and the smallest in the group 


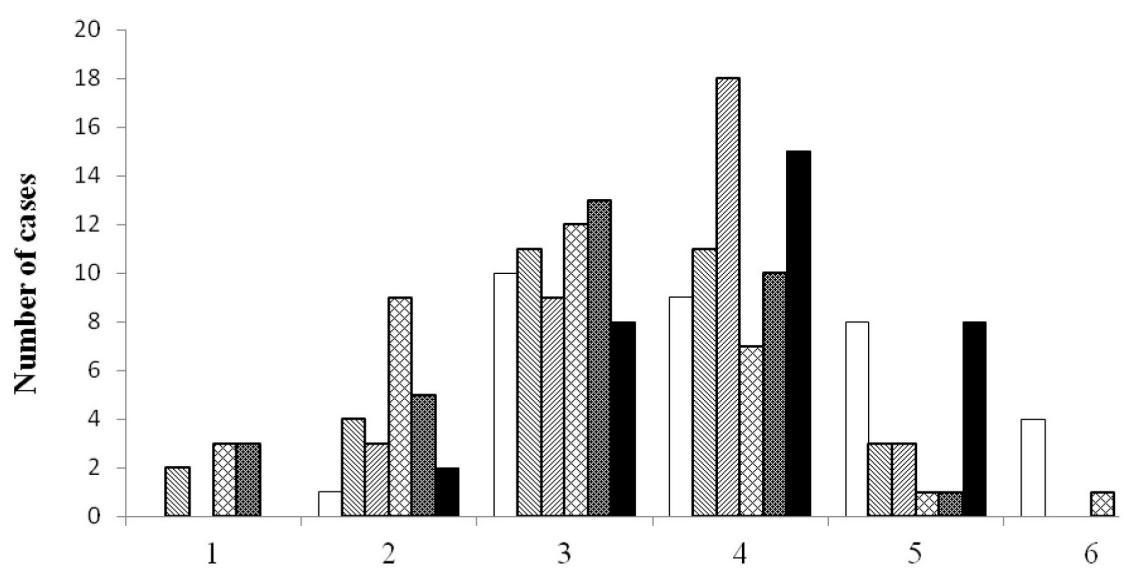

Number of amplification fragments per sample
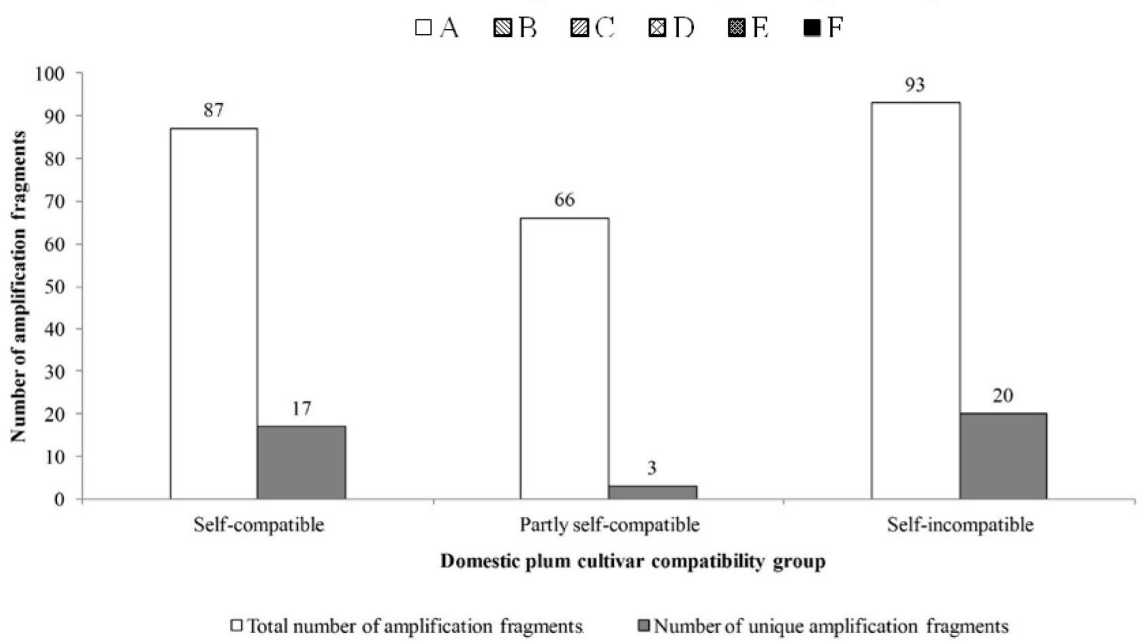

Fig. 2. Frequency of amplification fragments per sample detected in domestic plum ( $P$. domestica) cultivars by $S$-locus specific consensus primer pairs.
A - EM-PC2consFD/ EM-PC3consRD
B - EM-PC2consFD/ EM-PC5consRD
C - PruC2/ PCE-R
D - PruT2/ PCE-R
E - F-Box50A/ F-Box intronR
F - PasPcons-F1/ PaC1cons-R1

Table 2

CHARACTERISTICS OF S-RNASE AND SFB INTRON FLANKING CONSENSUS PRIMER PAIRS BY PLUM CULTIVAR SELF-COMPATIBILITY GROUP

Fig. 3. Number of amplification fragments detected by $S$-locus specific consensus primer pairs depending on the domestic plum ( $P$. domestica) compatibility group.

\begin{tabular}{|c|c|c|c|c|c|c|c|}
\hline & \multicolumn{6}{|c|}{ Consensus primer pair* } & \multirow[t]{2}{*}{ Average } \\
\hline & A & $\mathrm{B}$ & $\mathrm{C}$ & $\mathrm{D}$ & $\mathrm{E}$ & $\mathrm{F}$ & \\
\hline \multicolumn{8}{|c|}{ Group of self-compatible domestic plum cultivars } \\
\hline Gene diversity [PIC value] & 0.885 & 0.889 & 0.861 & 0.873 & 0.914 & 0.927 & 0.892 \\
\hline Number of amplification fragments & 15 & 12 & 11 & 13 & 16 & 20 & 14.5 \\
\hline \multicolumn{8}{|c|}{ Group of partly self-compatible domestic plum cultivars } \\
\hline Observed heterozygocity & 1.000 & 1.000 & 1.000 & 0.833 & 1.000 & 1.000 & 0.972 \\
\hline Gene diversity [PIC value] & 0.903 & 0.898 & 0.865 & 0.853 & 0.872 & 0.896 & 0.881 \\
\hline Number of amplification fragments & 12 & 11 & 9 & 9 & 10 & 12 & 10.5 \\
\hline \multicolumn{8}{|c|}{ Group of self-incompatible domestic plum cultivars } \\
\hline Observed heterozygocity & 1.000 & 0.867 & 1.000 & 0.938 & 0.813 & 1.000 & 0.936 \\
\hline Gene diversity [PIC value] & 0.924 & 0.902 & 0.878 & 0.892 & 0.880 & 0.932 & 0.901 \\
\hline \multicolumn{3}{|c|}{$*$ A - EM-PC2consFD/ EM-PC3consRD } & \multicolumn{4}{|c|}{ D - PruT2/ PCE-R } & \\
\hline \multicolumn{3}{|c|}{ B - EM-PC2consFD/ EM-PC5consRD } & \multicolumn{4}{|c|}{ E - F-Box50A/ F-Box intronR } & \\
\hline \multicolumn{3}{|l|}{$\mathrm{C}$ - PruC2/ PCE-R } & \multicolumn{4}{|c|}{ F - PasPcons-F1/ PaC1cons-R1 } & \\
\hline
\end{tabular}

of partly self-compatible plums (66). The group of self-incompatible plums had the highest number of unique fragments (20). Seventeen unique amplification fragments were identified in the group of self-compatible and three for partly self-compatible plums (Fig. 3). The highest number of amplification fragments was found for group of self-incompatible plums and the lowest in partly self-compatible cultivars (Table 2, Fig. 3). The highest heterozygocity was 
observed in the group of partly self-compatible plum cultivars (0.972), and the highest average gene diversity for the group of self-incompatible cultivars (0.901). Observed heterozygocity for self-compatible and partly self-compatible groups was higher than the average for the whole set of tested plum cultivars, and lower in the self-incompatible group (0.936 and 0.953, respectively) (Tables 1 and 2).

Although unique amplification fragments for the selected compatibility groups were identified, AMOVA detected only $5 \%$ difference among these groups of cultivars. For each primer pair, AMOVA identified amplification fragments that were able to distinguish cultivar compatibility groups (Table 1). For the primer pair spanning the $S$-RNase first intron, twelve amplification fragments differed among the groups of cultivars with average variability of $12.3 \%$. The primers pair spanning the $S$-RNase second intron had six to nine amplification fragments and the SFB intron primer pair had eight amplification fragments that could be used to discriminate compatibility groups (Table 1). Wide range of variability among self-compatibility groups was observed: from one to $42 \%$ of total allelic variability (Table $1)$. The lowest average variability among self-compatibility groups was found for the SFB intron primer pair (6.1\%), and the highest for primer pair PruT2/ PCE-R (18.1\%) spanning the second intron of $S$-RNase gene.

PCA differentiated plum cultivars based on the selected amplification fragments, which corresponded to self-compatibility determined by the field observations (Fig. 4). Selfcompatible plum cultivars formed a close group, surrounded by cultivars representing partly self-compatible plums. Self-incompatible plums showed high diversity and formed several distant groups of cultivars (Fig. 4).

\section{DISCUSSION}

S-allele genotyping. Genotyping of domestic plum ( $P$. domestica L.) cultivars was performed using five $S$ locus specific consensus primer pairs that amplied the first and second intron of the the $S$-RNase coding region (Fig. 1) and one primer pair that amplified the SFB intron responsible for the pollen-associated self-compatibility. These markers were developed and used earlier to study genetics of self-compatibility in other Prunus species (Ushijima et al., 1998; Tao et al., 1999; Sutherland et al., 2004; Sonneveld et al., 2006; Vaughan et al., 2006; Guerra et al., 2009), with limited application in domestic plum (Sutherland et al., 2007). Successful amplification was detected for all primer pairs included in this study; one to six amplification fragments per cultivar were detected. The results confirmed high conservatism of $S$-gene among Prunus species and primer pair transferability, as already shown for primer pairs EM-PC2consFD/ EM-PC3consRD, EM-PC2consFD/ EM-PC5consRD, and Pru-C2/ PCE-R in cherries, almonds and apricots (Sutherland et al., 2004; Vieira et al., 2008). Primer pairs EM-PC2consFD/ EM-PC3consRD, EM-PC2consFD/ EM-PC5consRD, and PruT2/ PCE-R had not been used previously in domestic plum, but were found to ensure good applicability. Conservatism of the $S$-gene locus was supported also by the amplified fragment range of the same primer pairs used in different species. Similar length range of amplification fragments detected by the same primer pair was found in sweet cherries (Vaughan et al., 2006) and Japanese plums (Guerra et al., 2009).

Consensus primers showed good applicability for characterisation of plum germplasm and cultivar discrimination using a limited number of molecular markers. No identical genotypes were identified and discrimination of closely related clones was possible (e.g. six clones of cultivar 'Latvijas Dzeltenā Olplūme' collected in different locations of Latvia and from neighbouring countries). The applied primer pairs showed very high polymorphism, as 14-31 amplification fragments were detected in 33 domestic plum cultivars, with high observed heterozygocity (average 0.953 ) and PIC values (average 0.915) (Table 1). A similar number of amplification fragments for domestic plums was found also by Sutherland et al. (2007). Sutherland and colleagues (2007) pointed out that due to high polymorphism, application of primer pair PasPcons-F1/ PaC1cons-R1 spanning the first intron of $S$-RNse was sufficient for successful genotyping. Good applicability of this primer pair in the domestic plum cultivars was found earlier in previous studies

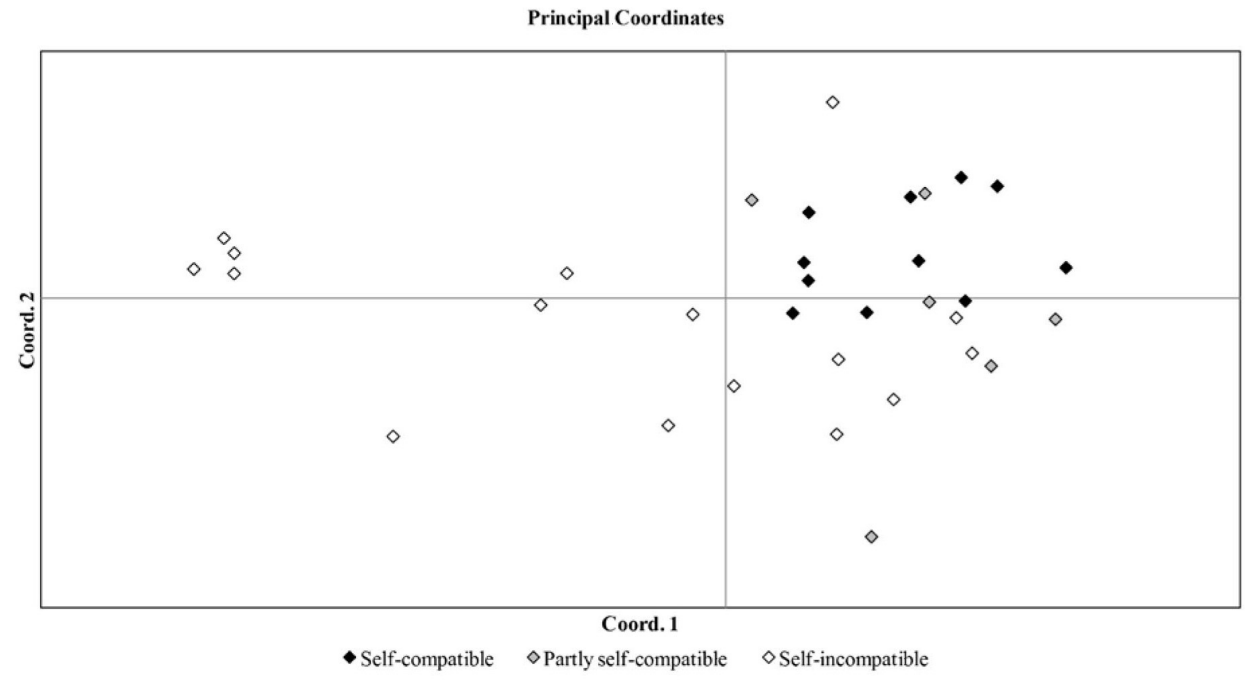

Fig. 4. PCA (principal component analysis) grouping of domestic plum $(P$. domestica) cultivars based on selected amplification fragments detected by $S$-locus specific consensus primer pairs. 
on Latvian plum self- compatibility. In those studies, 92 domestic plum and seven diploid plum cultivars of diverse origin were genotyped. In total 13 amplification fragments were detected in the domestic plums, with high observed heterozygocity (1.000) and gene diversity (PIC value 0.895), ensuring good applicability for characterisation of plum germplasm and cultivar discrimination using a limited number of markers (Kota and Lācis, 2013). In this study, primer pair PasPcons-F1/ PaClcons-R1 produced two to six amplification fragments for domestic plums (ranging from 231 to $415 \mathrm{bp}$ ), which is in the range detected for the same primer pair in sweet cherries (Vaughan et al., 2006), for which these primers were developed. In the investigation of Sutherland and colleagues (2007), primer pairs spanning the $2^{\text {nd }}$ intron were not sufficiently informative due to a narrow range of amplification fragments, difficulties in scoring scoring stuttered bands and excessive number of detected fragments (more than six per sample). Thus, it was suggested that primer pairs specific for the second intron were not suitable for genotyping. However, in our investigation all primer pairs spanning the second intron of $S$-RNase gene amplified up to six fragments. The lowest distance between bands was $20 \mathrm{bp}$, and thus the bands were well detectable on agarose gel. Therefore, markers specific for the second intron of $S$-RNase gene could be used for the genotyping of domestic plums, especially primer pair EM-PC2 cons FD/ EM-PC3 cons RD that had high polymorphism (20 amplification fragments detected, fragment length range 279-3000 bp, high heterozygocity (1.000) and PIC value (0.929) (Table 1). These results concur also with previous $S$-genotyping for primer pair Pru C2 / PCE-R, which revealed a high number of amplification fragments for domestic plums (15), high observed heterozygocity (0.967) and gene diversity value (0.880) (Kota and Lācis, 2013). Detailed information on domestic plum self-compatibility can not been acquired without considering pollen-associated compatibility. Therefore, primer pair F-Box50A/ F-Box intronR needs to be employed to ensure more complete characterisation. Based on the obtained results we suggest that primer pairs EM-PC2 cons FD/ EM-PC3 cons RD, PasP cons-F1/ PaC1 cons-R1 and F-Box 50A/ F-Box intron $\mathrm{R}$ can be used as supplementary markers in the characterisation and identification of plum genetic resources with potential functional relevance.

Plum compatibility groups. PCA grouping of cultivars based on $S$-genotyping (Fig. 4) was not in accordance with previous cultivar compatibility characterisation conducted by cultivar evaluation and field trials. Information about compatibility of these cultivars was collected from publications and field observations and trials. One of the reasons for this might be that particular alleles do not ensure selfcompatibility or self-incompatibility, and that allele combinations and their complex interactions are important. Domestic plum is a hexaploid allopolyploid species (Botu et al., 2002) for which inheritance of the $S$-gene has still not been elucidated. Although direct association among polyploidy and self-compatibility has not been observed (Mable, 2004), it may influence the compatibility reaction due to competition among alleles, as in sour cherries, or other mechanisms and demonstrate biases of the self-compatibility reactions. The functions of self-compatibility reactions of allopolyploid species have not been sufficiently studied (Mable, 2004). In addition, field observations and trials need to be supported by cytoembryological investigations, since pollination processes are affected by the environment, which may hide heredity or modify its external manifestation. Although the applied markers could not strictly distinguish selected plum cultivars according to compatibility groups (self-compatible, partly self-compatible and self-incompatible), group unique amplification fragments were identified (Fig. 3), which could serve as a baseline in further development of specific markers.

AMOVA was applied to evaluate the differences among plum compatibility groups and to select amplification fragments potentially applicable for discrimination of the groups. Although variability between self-compatibility groups was low (5\%), six to twelve fragments that significantly differed between the groups were identified, which ensured the discrimination of self-compatibility groups (Table 1). These alleles accounted for 6.1 to $18.1 \%$ of the variability among plum cultivar groups. Selected amplification fragments were used in subsequent PCA to test their discrimination and grouping power (Fig. 4). Analysis of selected amplification fragment data showed correlation with phenotypical observations, as expected. The highest diversity was found among self-incompatible plum cultivars (Fig. 4). They formed a diffuse group with several closely related sub-groups, which could be used for further designation of domestic plum cultivar cross compatibility groups.

\section{ACKNOWLEDGEMENTS}

This research was supported from the project No. 09.1067/229 financed by the Latvian Council of Science.

\section{REFERENCES}

Botu, M., Şarpe C., Cosmulescu, S. (2002). The genetic control of pollen fertility, pollenizing and fruit set for the Prunus domestica L. plum cultivars. Acta Hort., 577, 139-145.

Decroocq, V., Hagen, L. S., Favé, M. G., Eyquard, J. P., Pierronnet A. (2004). Microsatellite markers in the hexaploid Prunus domestica species and parentage lineage of three European plum cultivars using nuclear and chloroplast simple-sequence repeats. Mol. Breed., 13, 135-142.

Donoso, J. M., Aros, D., Meneses, C., Infante, R. (2009). Identification of S-alleles associated with self-incompatibility in apricots (Prunus armeniaca L.) using molecular markers. J. Food Agricult. Environ., 7 (3/4), 270-273.

Guerra, M. E., Rodrigo, J., Lopez-Corrales, M., Wünsch, A. (2009). S-RNase genotyping and incompatibility group assignment by PCR and pollination experiments in Japanese plum. Plant Breed., 128, 304-311.

Hegedüs, A., Halįsz, J. (2007). Recent findings of tree fruit self-incompatibility studies. Int. J. Hort. Sci., 13, 7-15.

Ipek, A., Gulen, H., Akcay, M. E., Ipek, M., Ergin, S., Eris, A. (2011). Determination of self-incompatibility groups of sweet cherry genotypes from Turkey. Gen. Mol. Res., 10 (1), 253-260. 
Jie, Q., Shupeng, G., Jixiang, Z., Manru, G., Huairui, S. (2005). Identification of self-incompatibility genotypes of apricot (Prunus armeniaca L.) by S-allele-specific PCR analysis. Biotechnol. Lett., 27, 1205-1209.

Kārkliņ̌̌, J., Skrīvele, M., Kaufmane, E., Ikase, L. (2007). Plūmju šķirnes [Plum Cultivars]. Dobele: Latvijas Valsts augḷopības institūts. 204 lpp. (in Latvian).

Kaufmane, E. (1991). Plūmju reproduktīvās sfrēras attīstības citoembriologiskais raksturojums [The cytoembryological characteristics of the development of plum reproductive sphere]. Doctoral thesis. Rìga, Latvijas Zemkopības ZPI. 164 lpp. (in Latvian)

Kaufmane, E., Lacis, G., Ikase L. (2006). Current situation of the Latvian Prunus collections: Conservation, evaluation and characterization for the establishment of core collections. Report of a Working Group on Prunus. Biodiversity International, pp. 66-74.

Kota, I., Lācis, G. (2013). Evaluation of genetic diversity in plum germplasm collection using DNA-based S-genotyping. Acta Hort., 985, 35-42.

Lacis, G., Kaufmane, E., Rashal, I., Trajkovski, V., Iezzoni, A. F. (2008). Identification of self-incompatibility $(S)$ alleles in Latvian and Swedish sweet cherry genetic resources collections by PCR based typing. Euphytica, 160, 155-163.

Mable, B. K. (2004). Polyploidy and self-compatibility: Is there an association? New Phytologist, 162, 803-811.

Peakall, R., Smouse, P. E. (2006). GENALEX 6: Genetic analysis in Excel. Population genetic software for teaching and research. Mol. Ecol. Notes, 6 , 288-295.

Salesses, G., Bonnet, A. (1994). Citological studies of tetra-, hepta-, and octoploid interspecific hybrids between $P$. cerasifera, $P$. spinosa and $P$. domestica. Acta Hort., 359, 26-32.

Sonneveld, T., Robbins, T. P., Tobutt K. R. (2006). Improved discrimination of self-incompatibility $S$-RNase alleles in cherry and high throughput genotyping by automated sizing of first intron polymerase chain reaction products. Plant Breed., 125, 305-307.
Sutherland, B. G., Cerovič, R., Robbins, T. P., Tobutt, K. R. (2009). The myrobalan (Prunus cerasifera L.): A useful diploid model for studying the molecular genetics of self-incompatibility in plums. Euphytica, 166, 385-398.

Sutherland, B. G., Robbins, T. P., Tobutt, K. R. (2004). Short communication primers amplifying a range of Prunus $S$-alleles. Plant Breed., 123, 582-584.

Sutherland, B. G., Tobutt, K. R., Robbins, T. P. (2007). Molecular genotyping of self-incompatible plum cultivars. Acta Hort., 734, 47-51.

Tao, R., Yamane, H., Sugiura, A., Murayama, H., Sassa, H., Mori, H. (1999). Molecular typing of $S$-alleles through identification, characterization and cDNA cloning for S-RNases in sweet cherry. J. Amer. Soc. Hort. Sci., 124, 224-233.

Tao, R., Iezzoni, A. F. (2010). The $S$-RNase-based gametophytic self-incompatibility system in Prunus exhibits distinct genetic and molecular features. Scientia Hort., 124, 423-433.

Tsukamoto, T., Tao, R., Iezzoni, A. F. (2008). PCR markers for mutated $S$-haplotypes enable discrimination between self-incompatible and selfcompatible sour cherry selections. Mol. Breeding., 21, 67-80.

Ushijima, K., Sassa, H., Tao, R., Yamane, H., Dandekar, A. M., Gradziel, T. M., Hirano, H. (1998). Cloning and characterization of cDNAs encoding $S$-RNases from almond (Prunus dulcis): Primary structural features and sequence diversity of the SRNases in Rosaceae. Mol. Genet. Genom., 260, 261-268.

Vaughan, S. P., Russell, K., Sargent, D. J., Tobutt, K. R. (2006). Isolation of $S$-locus F-box alleles in Prunus avium and their application in a novel method to determine self-incompatibility genotype. Theor. Appl. Genet., 112, 856-866.

Vieira, J., Santos, R. A. M., Habu, T., Tao, R., Vieira, C. P. (2008). The Prunus self-incompatibility locus ( $S$ locus) is seldom rearranged. J. Hered., 99 (6), 657-660.

Zohary, D., Hopf, M. (2000). Domestication of Plants in the Old World the Origin and Spread of Cultivated Plants in West Asia, Europe and the Nile Valley. Oxford: Oxford University Press. $316 \mathrm{pp}$

Received 10 October 2012

\section{MĀJAS PLŪMJU (Prunus domestica L.) PAŠNESADERĪBAS LOKUSA DAUDZVEIDĪBAS NOVĒRTĒJUMS, IZMANTOJOT $S$-GENOTIPĒŠANU}

Joprojām ir nepietiekama informācija par pašnesaderības iedzimšanu mājas plūmēm ( $P$. domestica L.). Salīdzinājumā ar citām Prunus sugām, tām nav izstrādāti $S$-alēlēm specifiski molekulārie marḳieri, identificētas šḳirņu saderības grupas, nav zināma pašnesaderības lokusa daudzveidība. Tāpēc, izmantojot sešus citām Prunus sugām izstrādātos $S$-lokusam specifiskos molekulāros markierus, tika veikta 33 mājas plūmju genotipēšana. Lietotie markieri uzrādīja labu starpsugu pārnesi un nodrošināja augstu ǵenētisko daudzveidību (konstatēti 14-37 amplifikācijas fragmenti, vidējā heterozigotāte - 0,953). Izmantotie molekulārie marḳieri uzrādīja augstu izšķirtspēju un nodrošināja visu pētījumā iekḷauto mājas plūmju škirṇu identifikāciju. Pamatojoties uz iegūtajiem rezultātiem, praimeru pāri EM-PC2consFD/ EM-PC3consRD, PasPcons-F1/ PaC1cons-R1 un F-Box50A/ F-Box intronR tiek rekomendēti kā papildus markieri plūmju augu materiāla raksturošanai un identifikācijai. Lai gan pētījumā lietotie molekulārie marḳieri nespēja grupēt plūmju škirnes pēc to piederības pašsaderības gupām (pašsaderīgas, dalẹji pašsaderīgas un pašnesaderīgas), tika identificēti katrai no šīm grupām unikāli amplifikācijas fragmenti, kas izmantojami turpmākajā darbā, izstrādājot saderības grupām specifiskos marḳierus. 